\title{
Ecosystem dynamics and services of a paired Neotropical montane forest and pine plantation
}

\author{
Zdravko Baruch $^{1,2 *}$, Shingo Nozawa ${ }^{3}$, Erica Johnson ${ }^{1} \&$ Edgard Yerena ${ }^{1}$ \\ 1. Departamento de Estudios Ambientales. Universidad Simón Bolívar. Apartado 80659. Caracas 1080, Venezuela; \\ johnson.ojeda@gmail.com, eyerena@usb.ve \\ 2. School of Biological Sciences. University of Adelaide, North Terrace, South Australia 5005; \\ zdravko.baruch@adelaide.edu.au \\ 3. Instituto Experimental Jardín Botánico “Dr. Tobías Lasser”, Caracas, Venezuela; s.nozawa@gmail.com \\ * Correspondence
}

\author{
Received 27-V-2018. Corrected 14-X-2018. Accepted 23-I-2019.
}

\begin{abstract}
Montane forests are one of the most decimated of Neotropical biomes even though they provide a suite of valuable ecosystem services such as provision of water to lowland settlements and prevention of erosion and mudslides. In some instances, to restore these and other ecosystem services, degraded montane forests are replaced by exotic tree plantations, which cover sizeable areas in several countries. Despite their importance for assessment of ecological services and for intrinsic ecological value, comparative studies of paired native montane forest and conifer plantation are scarce along the Northern Andean Cordillera. Additionally, extrapolations are challenging because each pair of communities is highly site specific due to environmental setting, age and density of plantation, and reforestation species. Here, we assess and compare structure, biogeochemistry and ecosystem services provided by closely positioned native forest and pine plantation from a protected montane area in Venezuela. Soil nutrients and soil carbon content were 60 and $54 \%$ respectively higher in the forest. As consequence of pine' growth form and leaf biochemistry, aboveground biomass and litter mass, as well as nutrient content and carbon stocks, were higher in the plantation. This results in the plantation storing $30 \%$ more $\mathrm{MgC} \mathrm{ha}^{-1}$ than the nearby forest. Canopy structure and litter properties influence the hydrology of both ecosystems through differences in rain throughfall. Most of the ecosystem services itemized are superior in the native forest, with exception that the younger plantation sequesters more carbon. An additional service provided by plantations might be that of ecological corridors that connect fragmented native forests. Our study, a specific case of nutrient and carbon cycling dynamics in paired montane forests and pine plantations, provides another set of data for the design of policy and management of considerable areas in the Neotropics with established conservation plantations.
\end{abstract}

Key words: biogeochemistry; conifer plantation; ecosystem services; hydrology; montane forest; Neotropics.

Baruch, Z., Nozawa, S., Johnson, E., \& Yerena, E. (2019). Ecosystem dynamics and services of a paired Neotropical montane forest and pine plantation. Revista de Biología Tropical, $67(1), 24-35$.

Montane forests are one of the most decimated Neotropical biomes (Howorth \& Pendry, 2006; Armenteras, Rodríguez, Retana, \& Morales, 2010; Meier, 2011; Portillo-Quintero, Lacabana, \& Carrasquel, 2011). Many have been destroyed for either firewood or charcoal production or cleared for crops, pastures and urban settlements. Some of them enclose shade coffee farms (Chazdon, 2008; Perfecto \& Vandermeer, 2008).

After deforestation, the land is commonly covered by native and African invasive grasses 
and left for cattle grazing while secondary succession is arrested by soil loss through erosion and by recurrent fires (Chazdon, 2008; Lugo, 2009). Consequently, the hydrologic cycle is altered causing reduced water delivery for downslope human settlements during the dry season, while catastrophic mudslides occur in the rainy season. There is a partial recovery of the hydrologic cycle services through afforestation of bared areas with protective plantations of exotic trees (mostly Pinus and Cupressus species). In addition, the plantations prevent erosion, provide habitat for local biodiversity (Cavelier \& Tobler, 1998; Brockerhoff, Jactel, Parrotta, Quine, \& Sayer, 2008; Baruch, Johnson, \& Yerena, 2016) and improve landscape appearance and appeal.

In Colombia, Costa Rica, Ecuador and Venezuela, approximately 200000 ha (Discounting $\sim 500000$ ha from the extensive Pinus caribaea plantations in the Venezuelan Orinoco savannas) have been reforested with exotic species (FAO, 2015). For lack of precise data, a prudent estimate of 1 to $2 \%$ of that area was reforested with conifers and established for conservation purposes, mainly watershed protection. However, contrary to the secondary forest, the exotic conifers are relatively short lived and the plantations are often mismanaged and burned, gradually losing the services that they provide. To break this cycle of degradation - afforestation - degradation and to provide ecological services on a long term basis, these lands must be restored. To adequately assess the progress and outcome of restoration, diversity and structure of the vegetation and the biogeochemistry of the ecosystem under restoration must be compared to that of a desired target or reference under similar environments (McDonald, Gann, Jonson, \& Dixon, 2016).

Despite the relatively large area covered by protective and conservation plantations, little comparative research has been done even though reforested areas complement the ecological value of the secondary forests (Chazdon, 2008; Chazdon et al., 2016). Here, we integrate previous studies (Baruch \& Nozawa, 2014; Baruch et al., 2016) and unpublished results, to contrast a montane forest with an adjacent pine plantation in terms of vegetation traits, ecosystem dynamics and in the provision of several ecological services listed in current agendas (Millennium Ecosystem Assessment, 2005).

\section{MATERIALS AND METHODS}

Study site and vegetation sampling: Forest and plantation face each other on opposite slopes (15-30\% inclination) within the protected Ecological Reserve of Universidad Simón Bolívar (USB) in the Venezuelan Coastal Mountains $\left(10^{\circ} 24^{\prime} \mathrm{N} \& 66^{\circ} 53^{\prime} \mathrm{W}\right.$; at 1100 - 1450 m.a.s.l.) (Fig. 1). Here, climate is temperate (mean air temperature $=20.2{ }^{\circ} \mathrm{C}$ ) with most rains from May to November (annual mean rainfall $=1113 \mathrm{~mm}$ ). Plantation soils are relatively shallow whereas forest soils are somewhat deeper Ultisols. The even-aged plantation sown mostly with the exotic Caribbean pine (Pinus caribaea Mortelet) at 1350 trees ha $^{-1}$ (AGROFORCA, 1990) was $\sim 40$ years old at the time of the study and its northern section extends over 48 ha on south facing slopes (Fig. 1). It was established to shield the USB campus from rainy season mudslides and that mission was well accomplished for $>30$ years (personal observation). This plantation also delivers recreational and educational services and greatly improves the landscape appearance. It is relatively protected from fire but otherwise unmanaged nor commercial use was ever attempted (Baruch et al., 2016). Several shrubs (Clidemia sp., Miconia sp.), and graminoids (Melinis minutiflora and Scleria sp.) are found in the periphery of the plantation. On the opposite north facing slope, are 103 ha of an ombrophilous lower montane cloud forest (Huber \& Alarcón, 1988; Bruijnzeel, Mulligan, $\&$ Scatena, 2011) that surround nine hectares of a long ( $>60$ years) abandoned coffee plantation. Here, secondary succession has removed most of the evidences of previous cultivation but some areas were invaded by the alien tree Syzygium jambos (rose-apple) (Baruch \& Nozawa, 2014). 

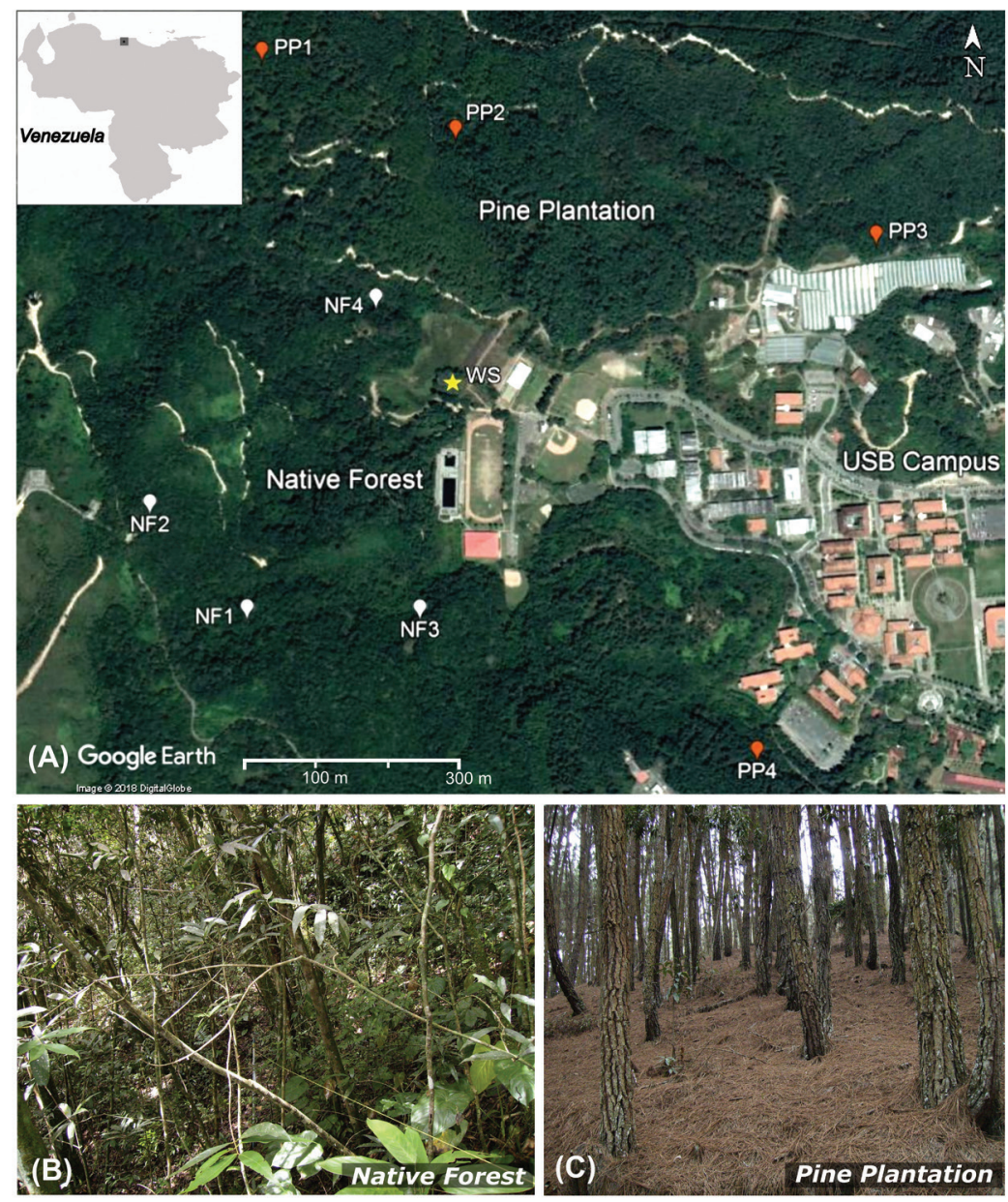

Fig. 1. A) Native forest (NF) and pine plantation (PP) plots within the Ecological Reserve of Universidad Simón Bolívar campus in Caracas. Insert shows approximate location in the Central Coastal Mountains, Venezuela. The star symbol shows the location of the external weather station. Estimated scale 1:10 000. B) Sub-canopy structure of the montane forest. C) Interior of the pine plantation showing the extent of litter.

Four $20 \times 20 \mathrm{~m}$ permanent plots were established within the native forest (NF) and in the pine plantation (PP) (Fig. 1). The plots were divided into four $100 \mathrm{~m}^{2}$ quadrants to facilitate surveys. In the forest, shrubs and trees with trunk diameter $>2.5 \mathrm{~cm}$ at breast height $(\mathrm{DBH})$ were tallied, as well as all plantation trees. DBH was converted to basal area (BA). Concurrently, tree density (D) and approximate height were scored. Botanical samples were identified following Hokche et al. (2008).
Climate and soils: Air temperature, relative humidity and rainfall were monitored within the forest, the plantation and in a weather instrument shelter uncovered by vegetation. Data were recorded every 15 min with loggers (HoBo, model H08-032-08, ONSET, Bourne, MA, USA) and standard pluviometers. Rainfall interception by vegetation and throughfall were calculated from the difference between that in the open and that below the canopy. Due to logistic limitations, data shown do not 
always correspond to identical times. Canopy cover and leaf area index (LAI) were measured during the same day with hemispheric photography and the images were analyzed as in Baruch et al. (2016).

To describe soil properties from both stands, three soil samples, 5 to $20 \mathrm{~cm}$ deep, were taken at $\sim 5 \mathrm{~m}$ from the center of each plot and mixed for uniformity. Texture (Bouyoucos, 1962), pH (1: 2.5 in water) and organic matter content [Walkley \& Black's method (Jackson, 1982)] were determined. Available phosphorus was extracted as in Mehlich (1984) and analyzed with the molybdic-blue method (Murphy \& Riley, 1962) and available potassium and calcium by flame spectrophotometry. Total nitrogen was measured after Kjelhdal digestion. Cation exchange capacity (CEC) and exchangeable aluminium content were determined by extraction with $\mathrm{NH}_{4} \mathrm{Cl}$ followed by spectrophotometry (Sparks, Page, Helmke, \& Loeppert, 1996). In each plot, three samples for soil apparent density were cored with a cylinder then dried and weighed. Soil apparent density at $0.1 \mathrm{~m}$ depth converted soil nutrient concentration to mass by hectare in order to obtain consistent comparisons. Soil litter was collected with a circular sampler from the center of each of the four quadrants/plot in the forest and plantation then dried and weighed. Litter nutrient and carbon content was determined as above but could not be replicated in the plantation and results are shown only for discussion.

Data analyses: Tree standing biomass (Y) was estimated from stand tables of tallied DBHs as described and calculated by Brown (1997) and then converted to $\mathrm{Mg} \mathrm{ha}^{-1}$. For the forest, we selected the regression $\mathrm{Y}=42.69$ - $12.800(\mathrm{DBH})+1.242\left(\mathrm{DBH}^{2}\right)$ provided for moist habitats. For $P$. caribaea we employed the equation $\mathrm{Y}=\exp [-1.17+2.11(\ln \mathrm{DBH})]$. Carbon content in the biomass and litter was assumed as $50 \%$ of dry biomass (Houghton, 2005). Specific leaf area (SLA) was determined on 10 sun exposed randomly selected leaves of the most prominent forest trees (Baruch \&
Nozawa, 2014). Leaf disks of known area were dried for 48 hours at $60{ }^{\circ} \mathrm{C}$ and weighed. Leaf mineral contents were determined on ground composite samples as stated above.

For each plot, soil traits, LAI and canopy cover were averaged from the values of the four quadrants. Plot basal area, biomass and stem density was obtained by adding the values of the four quadrants. SLA was the average of the ten replicates per tree species. Where appropriate, differences between the four forest and four plantation plots were statistically tested with one-way ANOVAs (SYSTAT, 2002).

The interpretation of the results of this study should consider some limitations. Due to lack of equipment, micrometereological and rain throughfall measurements were not taken at the same time in forest and plantation. In addition, low replication, consequence of the relatively small study area could affect statistical interpretation of results.

\section{RESULTS}

Both soils are similarly sandy, acidic and relatively high in aluminium, but soil apparent density is $25.5 \%$ higher in the plantation (Table 1). Carbon, all mineral content and the CEC are significantly higher in forest soils (Table 1). Soil $\mathrm{C} / \mathrm{N}$ and N/P ratios did not differ among the vegetation types. Litter mass was much higher in the plantation, but litter N, P, Ca and $\mathrm{K}$ content were 3 to 10 times lower than in the forest soils (Table 1 ). Litter $\mathrm{C} / \mathrm{N}$ ratio was higher in the plantation, but the N/P ratio was higher in the forest (Table 1). On an area basis, the higher apparent density of plantation soils increases its carbon and mineral nutrient content more than in forest soils, but the differences remain as stated above (Table 1).

Due to the large fluctuations in air temperature and humidity, data are shown only for discussion (Table 2). On average, both canopies buffered microclimate as compared to the exterior. Mean monthly maximum air temperature was lower, but minimum air temperature and relative humidity were higher in the forest interior than outside (Table 2). 
TABLE 1

Mean, standard deviation, replicates, ANOVA's F-ratio and P of soil traits and litter mass and mineral concentration. Carbon and nutrient content of soils and litter on an area basis are also displayed

\begin{tabular}{|c|c|c|c|c|}
\hline Trait & Native forest & Pine plantation & F-ratio $_{(\mathrm{df})}$ & $\mathrm{P}$ \\
\hline Bulk Density $\left(\mathrm{g} \mathrm{cm}^{-2}\right)$ & $0.73 \pm 0.13(4)$ & $0.98 \pm 0.13(4)$ & $7.02_{(1,6)}$ & 0.038 \\
\hline Sand $(\%)$ & $49.06 \pm 2.06(4)$ & $50.81 \pm 7.16(4)$ & $0.22_{(1,6)}$ & 0.655 \\
\hline Clay $(\%)$ & $21.06 \pm 3.23(4)$ & $15.72 \pm 9.11(4)$ & $1.21_{(1,6)}$ & 0.312 \\
\hline $\mathrm{pH}\left(\mathrm{H}_{2} \mathrm{O}\right)$ & $4.82 \pm 0.44(4)$ & $4.65 \pm 0.36(4)$ & $0.33_{(1,6)}$ & 0.586 \\
\hline Carbon $(\%)\left(\mathrm{Mg} \mathrm{ha}^{-1}\right)$ & $4.62 \pm 1.33$ (4) 33.71 & $1.58 \pm 0.96(4) 15.56$ & $13.52_{(1,6)}$ & 0.010 \\
\hline Total Nitrogen $(\%)\left(\mathrm{Mg} \mathrm{ha}^{-1}\right)$ & $0.31 \pm 0.08$ (4) 2.26 & $0.09 \pm 0.04$ (4) 0.89 & $19.68_{(1,6)}$ & 0.004 \\
\hline CEC (meq $100 \mathrm{~g}^{-1}$ ) & $21.68 \pm 6.11(4)$ & $9.81 \pm 4.94(4)$ & $9.11_{(1,6)}$ & 0.023 \\
\hline Phosphorus (ppm) (Mg ha-1) & $6.50 \pm 1.47$ (4) 0.04 & $3.50 \pm 1.73(4) 0.03$ & $6.96_{(1,6)}$ & 0.038 \\
\hline Calcium $\left(\mathrm{cmol} \mathrm{kg}^{-1}\right)\left(\mathrm{Mg} \mathrm{ha}^{-1}\right)$ & $2.48 \pm 1.35(4) 0.31$ & $0.56 \pm 0.41(4) 0.11$ & $7.48_{(1,6)}$ & 0.033 \\
\hline Magnesium $\left(\mathrm{cmol} \mathrm{kg}^{-1}\right)\left(\mathrm{Mg} \mathrm{ha}^{-1}\right)$ & $1.27 \pm 0.78(4) 0.11$ & $0.19 \pm 0.08$ (4) 0.02 & $7.43_{(1,6)}$ & 0.034 \\
\hline Potassium $\left(\mathrm{cmol} \mathrm{kg}^{-1}\right)\left(\mathrm{Mg} \mathrm{ha}^{-1}\right)$ & $0.37 \pm 0.17$ (4) 1.07 & $0.07 \pm 0.02$ (4) 0.02 & $11.62_{(1,6)}$ & 0.014 \\
\hline Aluminium $\left(\mathrm{cmol} \mathrm{kg}^{-1}\right)\left(\mathrm{Mg} \mathrm{ha}^{-1}\right)$ & $3.89 \pm 1.05$ (4) 0.21 & $4.30 \pm 2.24(4) 0.37$ & $0.10_{(1,6)}$ & 0.756 \\
\hline SOIL $\mathrm{C} / \mathrm{N}$ ratio & $14.95 \pm 1.13(4)$ & $16.33 \pm 3.56(4)$ & $0.55_{(1,6)}$ & 0.486 \\
\hline Soil N/P ratio & $528.33 \pm 65.68(4)$ & $317.5 \pm 192.28(4)$ & $4.30_{(1,6)}$ & 0.083 \\
\hline Litter Mass $\left(\mathrm{g} \mathrm{m}^{-2}\right)$ & $686.1 \pm 220.5(4)$ & $3020.1 \pm 729.6(4)$ & $37.50_{(1,6)}$ & $<0.001$ \\
\hline Litter Carbon $\left(\mathrm{g} \mathrm{m}^{-2}\right)\left(\mathrm{Mg} \mathrm{ha}^{-1}\right)$ & $343.0 \pm 110.2(4) 3.43$ & $1510.0 \pm 364.8$ (4) 15.10 & $37.50_{(1,6)}$ & $<0.001$ \\
\hline Litter Nitrogen $(\%)\left(\mathrm{Mg} \mathrm{ha}^{-1}\right)$ & $1.95 \pm 0.68(3) 0.13$ & 0.58 (1) 0.04 & - & - \\
\hline Litter Phosphor. (ppm) $\left(\mathrm{Mg} \mathrm{ha}^{-1}\right)(\mathrm{Mg} / \mathrm{Ha})$ & $0.12 \pm 0.07(3) 82 \times 10^{-6}$ & $0.02(1) 13 \times 10^{-6}$ & - & - \\
\hline Litter Potassium $(\%)\left(\mathrm{Mg} \mathrm{ha}^{-1}\right)(\mathrm{Mg} / \mathrm{Ha})$ & $0.7 \pm 0.11(2) 0.04$ & $0.12(1) 0.06$ & - & - \\
\hline Litter Calcium (\%) $\left(\mathrm{Mg} \mathrm{ha}^{-1}\right)(\mathrm{Mg} / \mathrm{Ha})$ & $1.35 \pm 0.51(3) 0.09$ & $0.36(1) 0.10$ & - & - \\
\hline Litter $\mathrm{C} / \mathrm{N}$ ratio & $27.52 \pm 8.07(3)$ & $86.20(1)$ & - & - \\
\hline Litter N/P ratio & $17 \times 10^{4} \pm 3 \times 10^{4}(3)$ & $29 \times 10^{4}(1)$ & - & - \\
\hline
\end{tabular}

Soil values calculated to $0.1 \mathrm{~m}$ depth according to respective soil bulk densities.

Carbon content of litter is accounted as $50 \%$ of dry weight.

$\left(\mathrm{Mg} \mathrm{ha}^{-1}\right)$ nutrient content on an area basis.

(n) replicates.

TABLE 2

Mean, standard deviation, ANOVA's F-ratio and $\mathrm{P}$ of microclimatic variables and vegetation traits

\begin{tabular}{|c|c|c|c|c|c|}
\hline & Montane Forest & Pine Plantation & Climatic Station & $F_{(d f)}$ & $\mathrm{P}$ \\
\hline Maximum air temperature $\left({ }^{\circ} \mathrm{C}\right)$ & $23.66 \pm 3.32$ & $24.70 \pm 2.34$ & $24.97 \pm 1.68$ & - & - \\
\hline Minimum air temperature $\left({ }^{\circ} \mathrm{C}\right)$ & $15.83 \pm 1.54$ & $16.17 \pm 1.68$ & $15.69 \pm 1.53$ & - & - \\
\hline Minimum relative humidity (\%) & $81.46 \pm 13.57$ & $73.05 \pm 15.25$ & $66.78 \pm 10.26$ & - & - \\
\hline Canopy cover (\%) & $79.70 \pm 2.60$ & $75.94 \pm 2.36$ & - & $15.47_{(1-26)}$ & $<0.001$ \\
\hline LAI & $2.72 \pm 0.52$ & $2.23 \pm 0.55$ & - & $5.65_{(1-26)}$ & 0.025 \\
\hline Basal area $\left(\mathrm{m}^{2} \mathrm{ha}^{-1}\right)$ & $23.71 \pm 4.42$ & $60.62 \pm 3.91$ & - & $34.73_{(1-5)}$ & $<0.001$ \\
\hline Standing biomass $\left(\mathrm{Mg} \mathrm{ha}^{-1}\right)$ & $214.6 \pm 39.3$ & $348.7 \pm 62.3$ & - & $11.35_{(1-5)}$ & 0.015 \\
\hline Stem density $\left(\# \mathrm{ha}^{-1}\right)$ & $2268 \pm 517$ & $815 \pm 289$ & - & $29.12_{(1-5)}$ & 0.001 \\
\hline Height (m) (range) (estimated) & $10-20 \mathrm{~m}$ & $20-30 \mathrm{~m}$ & - & - & - \\
\hline Species richness (\# $\left.100 \mathrm{~m}^{-2}\right)$ (range) & $23-37$ & $8-20$ & - & - & - \\
\hline
\end{tabular}

Native forest data dismisses the NF1 plot due to heavy invasion by rose-apple. 
TABLE 3

Specific leaf area, mineral content and N/P ratio of selected species

\begin{tabular}{|c|c|c|c|c|c|c|}
\hline Forest species & SLA & $\% \mathrm{~N}$ & $\% \mathrm{Ca}$ & $\% \mathrm{P}$ & $\% \mathrm{~K}$ & $\mathrm{~N} / \mathrm{P}$ \\
\hline Inga sp. * & $52.8 \pm 6.6$ & 2.98 & 0.85 & 0.13 & 0.94 & 22.92 \\
\hline Ocotea fendleri $*$ & $87.8 \pm 5.1$ & 1.39 & 0.4 & 0.07 & 0.48 & 19.85 \\
\hline Croton megalodendron ** & $146.2 \pm 12.1$ & 3.11 & 1.1 & 0.2 & 0.86 & 15.55 \\
\hline Guatteria saffordiana ** & $186.1 \pm 29.2$ & 1.95 & 0.94 & 0.1 & 0.66 & 19.50 \\
\hline Miconia sp. ** & $138.0 \pm 17.7$ & 2.01 & 1.16 & 0.08 & 0.65 & 25.12 \\
\hline Syzigium jambos $* * *$ & $134.5 \pm 21.0$ & 1.14 & 0.71 & 0.08 & 0.66 & 14.25 \\
\hline Mean & 124.27 & 2.11 & 0.8 & 0.116 & 0.72 & 18.41 \\
\hline \pm std & 46.99 & 0.90 & 0.26 & 0.05 & 0.18 & 3.50 \\
\hline Pinus caribaea & na & 0.99 & 0.31 & 0.07 & 0.35 & 14.14 \\
\hline
\end{tabular}

Specific leaf area (SLA; $\mathrm{cm}^{2} \mathrm{mg}^{-1}$ )

* Evergreen/late successional, ** Semi-deciduous/early successional, *** Invader species (apple-rose).

Annual precipitation is notoriously variable in the area. Throughout the four years of this study, it ranged from $673 \mathrm{~mm}$ to $1607 \mathrm{~mm}$. The plantation canopy intercepted a monthly average of $25.9 \pm 13.8 \%$ of rainfall. Forest rain thoroughfall could be measured for only one year simultaneously with that of the plantation. During that period, mean monthly interception was higher and more variable in the forest (47.1 $\pm 18.9 \%)$ than in the plantation $(34.9 \pm 14.1$ $\%)$. Due to canopy architecture, cover and LAI were higher in the forest (Table 2).

One forest plot (NF1) was heavily invaded by rose-apple that considerably increased tree density, basal area and aboveground biomass (by $16 \%$ ) which were deleted for comparisons. Mean basal area and standing aboveground biomass of the plantation were significantly higher but stem density was lower than in the forest (Table 2). We estimated average forest tree height as $10 \mathrm{~m}$ whereas the pines were two to three times taller (Table 2).

The leaves of six of the most important semi-deciduous (pioneer) and evergreen (late successional) forest trees had approximately twice the nutrient content than pine needles, but their N/P ratio was similar (Table 3 ). The evergreens Inga sp. and Ocotea fendleri had the lowest SLAs, but leaf nutrient concentration did not differ among the groups (Table 3).

\section{DISCUSSION}

We discuss our results by comparing them to the scarce studies from Neotropical montane forests, where those by Lugo (1992) in Puerto Rico and by Cavelier and Tobler (1998) and León, González, and Gallardo (2011) in Colombia are prominent. However, we caution that these results are not readily comparable as our plantation is older and under a drier climate than those in Puerto Rico and Colombia. Also, planting density and conifer species also differ: 440-500 trees ha ${ }^{-1}$ of P. patula in Colombia, 850 trees ha ${ }^{-1}$ of $P$. caribaea in Puerto Rico and 1350 trees $^{-1} \mathrm{a}^{-1}$ in our study. Considering these limitations, we discuss the biophysical traits of our set of forest and plantation, their influence on biogeochemical and hydrological dynamics, the ecosystem services provided, and the challenges associated to human influences.

Substrate and microclimate: Soil texture and $\mathrm{pH}$ were similar in the forest and the plantation endorsing reports from the reference studies cited above, but contrasting to worldwide outcomes where densely spaced conifer plantations lead to soil acidification (Jackson et al., 2005; Berthrong, Jobbagy, \& Jackson, 2009). The higher soil apparent density of the plantation could be attributed to 
pre-afforestation conditions when soils were compacted by erosion and possibly by cattle trampling. Nutrient content was lower in the plantation soils even after adjustment due to different soil apparent densities. This could have been caused by previous leaching due to rainfall run-off, to the storage of most minerals in the larger standing pine biomass (Cuevas, Brown, \& Lugo, 1991; Jackson et al., 2005; Berthrong et al., 2009) or to the lower nutrient content in pine litter and its slower decomposition as discussed below. Our result differs from those from the benchmark studies that do not report systematic differences in soil nutrient content between forest and plantation. In terms of carbon, forest soil stocks were more than twice higher as the plantations' (33.7 vs. 15.5 $\mathrm{Mg} \mathrm{ha}^{-1}$ ). In relative terms, our result is similar to that of Cavalier and Tobler (1998) but differs from those of Lugo (1992), Li, Xu, Zou, Shi, and Zhang (2005) and León et al. (2011). Both discrepancies endorse the idiosyncratic nature of these comparative studies.

It has been persistently reported that native trees produce more or similar amounts of litter than tropical conifers (Lugo 1992; Li et al., 2005; Bakker, Carreño-Rocabado, \& Poorter, 2011; León et al., 2011; Ramirez et al., 2014). The larger build-up of conifer litter is caused by its lower decomposition rate due to low $\mathrm{N}$ and relatively high lignin content (Cuevas et al., 1991; Lugo, 1992; Cornwell et al., 2008; Bakker et al., 2011; Loaiza-Usuga et al., 2013; Ramirez et al., 2014). This is associated to the low mineral content in plantation soils and fertility loss (Cuevas \& Lugo, 1998; Bakker et al., 2011; Ramirez et al., 2014), but with a much larger carbon stored than in the forest litter (15.1 vs. $3.4 \mathrm{Mg} \mathrm{ha}^{-1}$ ). Conversely, the relatively high $\mathrm{N}$ content and SLA of native tree leaves (discussed below) promote their rapid litter decomposition (Cornwell et al., 2008; Bakker et al., 2011) and promotes higher soil nutrient content. Other litter traits such as particle size and shape that influence compaction and cohesion also correlate to decomposition, erosion, flammability and water infiltration (Lebrón, Robinson, Oatham, \& Wuddivira, 2012; Dias,
Cornelissen, Berg, \& de Vries, 2017). Furthermore, large conifer litter build-up obstructs the establishment of native plants (Fernández et al., 2006; Navarro-Cano, Barberá, \& Castillo, 2010; Bueno \& Baruch, 2011; Baruch et al., 2016). Finally, the large pine litter mass and its high flammability, due to large amounts of resin, are a latent hazard for plantations and nearby forests.

Throughfall was higher in our plantation by virtue of its more erect architecture, lower stem density as well as canopy cover (and LAI) and by the absence of epiphytes. Opposing results have been reported for the Colombian Andes and from a global study where throughfall was found to be lower in pine plantations (Jackson et al., 2005; León, González-Hernández, \& Gallardo-Lancho, 2010). These contrasting results, probably caused by differences in planting density, reiterate the idiosyncratic nature of our comparative approach. Periodic fog and cloud immersion probably provide substantial additional water to both forest and plantation that could reach $35 \%$ of annual precipitation as in a nearby forest (Gordon, Herrera, \& Hutchinson, 1994). Litter also interacts with hydrology as denser and thicker conifer litter retards water infiltration into soil (León et al., 2011) and promotes water repellency that increases run-off (Duque, Arbeláez, Jaramillo, \& León, 2004; Ruiz, Acosta-Jaramillo, \& León-Pelaez, 2005; Lebrón et al., 2012). Nevertheless, soil protection from direct rainfall impact provided by the plantation probably overrides litter caused run-off thus preventing erosion and mudslides.

Vegetation diversity, biomass and leaf traits: The architecture of the forest is more intricate than that of the plantation due to higher stem density, multilayer canopy and abundance of epiphytes as evidenced by higher cover and LAI. The canopy of the plantation is two to three times taller due to pines' life form and selection for fast growth. Species richness is obviously much higher in the forest but a few shrubs from the Melastomataceae family are shared by both communities (Baruch \& 
Nozawa, 2014; Baruch et al., 2016). Although these vegetation traits are comparable to other paired studies (Cuevas et al., 1991; Lugo, 1992; Cavelier \& Tobler, 1998), the heavy invasion of Syzygium jambos (rose-apple) in one of our forest plots is distinctive and strikingly increases forest basal area (Baruch \& Nozawa, 2014). A few shade tolerant forest trees were able to establish in the periphery of the pine canopy (Baruch et al., 2016), which is encouraging for restoration purposes although best results are obtained when pines are cleared or near plantation edges (Ashton, Gamage, Gunatilleke, \& Gunatilleke, 1997; Lugo, 2009; Baruch et al., 2016).

Despite its lower stem density, the plantation had significantly higher basal area, biomass and stored carbon than the forest, as in similar studies (Lugo, 1992; León et al., 2011). In Puerto Rico, a younger pine plantation had more than twice aboveground biomass than a secondary forest of the same age (Cuevas et al., 1991) as consequence of pines' growth form where a large proportion of assimilates is allocated to above ground tissues (Cuevas et al., 1991). Also, selection for fast growth in plantation conifers contributes to their large biomass that sequester relatively large amounts of carbon resulting in a valid strategy to offset $\mathrm{CO}_{2}$ emission. However, this higher carbon storage capacity trades-off with decreased soil fertility and stream flow, and increased soil acidity (Jackson et al., 2005). Although carbon content in our forest was close to the average for forests in Latin-America (Houghton, 2005), carbon storage in the plantation biomass was $39 \%$ higher (173.5 vs. $107.0 \mathrm{MgC} \mathrm{ha}^{-1}$ ). Due to their large biomass, plantations in Puerto Rico (Lugo, 1992) had more nutrients per unit area in standing vegetation than a paired forest and we would expect similar outcomes in our study. The differences in ecosystem dynamics between paired Neotropical montane forests and conifer plantations discussed so far are similar to those recognized worldwide (Chapman \& Chapman, 1996; Ashton, 1997; Brockerhoff et al., 2008; Arévalo, Delgado, \& Fernández-Palacios, 2011).
The montane forest encloses semi-deciduous and evergreen trees (Baruch \& Nozawa, 2014). The former are mostly pioneer species (Sobrado, 2003) with relatively short lived leaves whose specific leaf area is markedly higher than that of evergreens. This partially concurs with the leaf economy scheme (Wright et al., 2004) which also predicts that short lived leaves should display relatively high nutrient content, which we did not find probably due to our limited sample number. Pine needles have the lowest mineral content as a standard feature elsewhere (Lugo, 1992). Leaves from all species had relatively high N/P ratios meaning that $\mathrm{P}$ is more limiting to plant growth (Koerselman \& Meuleman, 1996), which was expected due to the low levels of soil P. These contrasting live leaf and litter traits and biochemical profile have profound influence on biogeochemical cycles and subsequently on ecosystem services.

Ecosystem services and threats: The differences in vegetation traits and biogeochemistry discussed so far influence a subset of the ecological services provided by our study ecosystems (Millennium Ecosystem Assessment, 2005; Brockerhoff et al., 2017). Because a large subset of ecological services is biodiversity dependent (Balvanera et al., 2006), the low species richness and the relatively simple architecture of even-aged pine plantations diminishes most services as compared to the forest. Habitat creation and fodder provisioning for fauna is a service clearly better suited in the forest. Few tropical birds and bats nest in the plantation nor feed on cones or seeds. Evidently, pollination services are highly diminished. The ecosystem stability and resilience are directly associated to the forests' higher diversity. However, the invasion of apple-rose cautions about the significance of these services. Conversely, the stability of the plantation is questioned by its large litter buildup and its flammability and the vulnerability to pests and pathogens. The diversity and complexity of the forest architecture favors recreation and contemplation. However, activities such as mountain bike, jogging and camping are easier in the more open plantation. 
The arrested succession in the plantation, non-strictly diversity related, is partially caused by obstructing germination and seedling emergence by the depth of the litter layer and by the allelopathic effects of pines (Fernández et al., 2006; Navarro-Cano et al., 2010). By virtue of its higher biomass and litter accumulation with slow decomposition, carbon storage and sequestration services are clearly favored in the plantation. Finally, the provision of soil nutrients is clearly superior in the native forest due to the high build-up of pines' low litter quality and slow decomposition that retards nutrient cycling. An additional potential service of exotic plantations could be that of providing ecological corridors that connect fragmented native forests. It is evident that, except for carbon sequestration, plantations have a limited ability to provide most services. However, even reduced, these services are more valuable than in plantations' absence (Chazdon, 2008).

Tropical montane forests, associated plantations and the services provided by them are challenged by rising human population and climate change. These challenges include: (a) Deprivation of water sources as increased temperature elevates cloud base and reduces fog frequency while increasing transpiration and water stress; (b) Imbalance of nutrient cycles due to excessive atmospheric $\mathrm{N}$ and toxic ions inputs in the vicinity of large cities; (c) Decimation through human deforestation and encroachment; (d) Shifts in vegetation composition and diversity caused by alien species invasion and (e) Increased fire hazard due to pine litter buildup and flammability and by more severe droughts.

Our study, a particular case of vegetation traits and biogeochemistry dynamics in paired montane forest and pine plantation, provides supplementary input data for the design of policy and management of considerable areas in the Neotropics with established conifer conservation plantations.

Ethical statement: authors declare that they all agree with this publication and made significant contributions; that there is no conflict of interest of any kind; and that we followed all pertinent ethical and legal procedures and requirements. A signed document has been filed in the journal archives.

\section{ACKNOWLEDGMENTS}

We thank Andrea Bueno for her assistance in initial plantation surveys and laboratory analyses. E. Zambrano, A. Castro and J. Mendoza provided essential logistic support throughout fieldwork. The Decanato de Investigaciones and Decanato de Extensión, Universidad Simón Bolívar supported this research.

\section{RESUMEN}

Dinámica y servicios del ecosistema en un bosque montano neotropical y un pinar sembrado Los bosques montanos son uno de los biomas más devastados del Neotrópico aunque proporcionan valiosos servicios ecológicos al suministrar agua a los asentamientos humanos y proteger contra la erosión y los deslaves. En algunas instancias, para mantener esos servicios ecológicos, los bosques destruidos son reemplazados por plantaciones forestales en áreas considerables de varios países. Aunque existen unos pocos estudios comparativos en a lo largo del norte de la Cordillera Andina, las extrapolaciones son difíciles debido a que estos son altamente específicos debido al entorno ambiental, edad de las plantaciones, y a la especie de conífera dominante. Nosotros analizamos y comparamos la diversidad y estructura de la vegetación, la biogeoquímica y los servicios ecológicos proporcionados por un bosque montano y una plantación de pino adyacente en un área protegida de Venezuela. Los suelos del bosque nativo contienen $60 \%$ más de nitrógeno y $54 \%$ más de carbono que los de la plantación. Como consecuencia de la forma de vida de los pinos y de su composición foliar, la biomasa aérea y el contenido de nutrientes en la hojarasca seca son mayores en la plantación dando como resultado que la plantación contiene $30 \% \mathrm{MgC} \mathrm{ha}^{-1}$ más que el bosque. La estructura del dosel influencia la hidrología de ambos ecosistemas mediante diferencias en la penetración del agua de lluvia. La mayoría de los servicios son de menor valor ecológico en la plantación de pino. Sin embargo, esta ofrece servicios que no existirían en su ausencia. En regiones montañosas, las plantaciones de coníferas fueron establecidas para mejorar la provisión de agua y estabilizar los suelos. Sin embargo, nuestros resultados sugieren que las plantaciones pueden proporcionar corredores ecológicos que conecten bosques nativos fragmentados. Nuestro estudio, al proveer un ejemplo adicional de dinámica ecológica comparada, expone las diferencias en servicios ecológicos proporcionados por un bosque montano y una plantación 
de pino y proporciona información para establecer políticas de conservación y manejo de recursos naturales en extensas áreas neotropicales.

Palabras clave: biogeoquímica; bosques montanos; hidrología; Neotrópicos; plantación de coníferas; servicios ecológicos.

\section{REFERENCES}

AGROFORCA. (1990). Informe técnico forestal para realizar un aclareo en el bosque de pino de la USB (Report para la Universidad Simón Bolívar). Caracas, Venezuela: Servicios Técnicos Agroforestales C.A.

Arévalo, J. R., Delgado, J., \& Fernández-Palacios, J. (2011). Regeneration of potential laurel forest under a native canopy vs. exotic canopy, Tenerife (Canary Islands). Forest Systems, 20(2), 255-265.

Armenteras, D., Rodríguez, N., Retana, J., \& Morales, M. (2010). Understanding deforestation in montane and lowland forests of the Colombian Andes. Regional Environmental Change, 11(3), 693-705. DOI: 10.1007/s10113-010-0200-y

Ashton, P., Gamage, S., Gunatilleke, I. A. U. N., \& Gunatilleke, C. V. S. (1997). Restoration of a Sri Lankan rainforest: Using Caribbean Pine Pinus caribaea as a nurse for establishing late-successional tree species. Journal of Applied Ecology, 34(4), 915-925.

Bakker, M. A., Carreño-Rocabado, G., \& Poorter, L. (2011). Leaf economics traits predict litter decomposition of tropical plants and differ among land use types. Functional Ecology, 25(3), 473-483. DOI: 10.1111/j.1365-2435.2010.01802.x

Balvanera, P., Pfisterer, A. B., Buchmann, N., He, J. S., Nakashizuka, T., Raffaelli, D., \& Schmid, B. (2006). Quantifying the evidence for biodiversity effects on ecosystem functioning and services. Ecology Letters, 9(10), 1146-1156.

Baruch, Z., Johnson, E., \& Yerena, E. (2016). What deters plant colonization in a tropical pine plantation? Revista de Biologia Tropical, 64(2), 461-471.

Baruch, Z., \& Nozawa, S. (2014). Abandoned coffee plantations: biodiversity conservation or path for nonnative species? Case study in a Neotropical montane forest. Interciencia, 39(8), 554-561.

Berthrong, S., Jobbagy, E., \& Jackson, R. (2009). A global meta-analysis of soil exchangeable cations, $\mathrm{pH}$, carbon, and nitrogen with afforestation. Ecological Applications, 19(8), 2228-2241.

Bouyoucos, G. J. (1962). Hydrometer method improved for making particle size analyses of soils. Agronomy Journal, 54(5), 464-465.
Brockerhoff, E. G., Barbaro, L., Castagneyrol, B., Forrester, D. I., Gardiner, B., Gonzalez-Olabarria, J. R., . . Jactel, H. (2017). Forest biodiversity, ecosystem functioning and the provision of ecosystem services. Biodiversity and Conservation, 26(13), 3005-3035. DOI: $10.1007 / \mathrm{s} 10531-017-1453-2$

Brockerhoff, E. G., Jactel, H., Parrotta, J. A., Quine, C. P., \& Sayer, J. (2008). Plantation forests and biodiversity: oxymoron or opportunity? Biodiversity and Conservation, 17(5), 925-951.

Brown, S. (1997). Estimating biomass and biomass change of tropical forests: a primer (Vol. 134). Rome: Food \& Agriculture Organization.

Bruijnzeel, L., Mulligan, M., \& Scatena, F. N. (2011). Hydrometeorology of tropical montane cloud forests: emerging patterns. Hydrological Processes, 25(3), 465-498.

Bueno, A., \& Baruch, Z. (2011). Soil seed bank and the effect of needle litter layer on seedling emergence in a tropical pine plantation. Revista de Biologia Tropical, 59(3), 1071-1079.

Cavelier, J., \& Tobler, A. (1998). The effect of abandoned plantations of Pinus patula and Cupressus lusitanica on soils and regeneration of a tropical montane rain forest in Colombia. Biodiversity and Conservation, $7(3), 335-347$.

Chapman, C. A., \& Chapman, L. J. (1996). Exotic tree plantations and the regeneration of natural forests in Kibale National Park, Uganda. Biological Conservation, 76(3), 253-257.

Chazdon, R. L. (2008). Beyond deforestation: restoring forests and ecosystem services on degraded lands. Science, 320(5882), 1458-1460. DOI: 10.1126/ science. 1155365

Chazdon, R. L., Broadbent, E. N., Rozendaal, D. M. A., Bongers, F., Almeyda-Zambrano, A. M.,... Poorter, L. (2016). Carbon sequestration potential of secondgrowth forest regeneration in the Latin American tropics. Science Advances, 2(5), 1501639.

Cornwell, W. K., Cornelissen, J. H., Amatangelo, K., Dorrepaal, E., Eviner, V. T., Godoy, O., . . . Westoby, M. (2008). Plant species traits are the predominant control on litter decomposition rates within biomes worldwide. Ecology Letters, 11(10), 1065-1071. DOI: 10.1111/j.1461-0248.2008.01219.x

Cuevas, E., Brown, S., \& Lugo, A. E. (1991). Above- and belowground organic matter storage and production in a tropical pine plantation and a paired broadleaf secondary forest. Plant and Soil, 135, 257-268.

Cuevas, E., \& Lugo, A. E. (1998). Dynamics of organic matter and nutrient return from litterfall in stands of ten tropical tree plantation species. Forest Ecology and Management, 112(3), 263-279. 
Dias, A. T. C., Cornelissen, J. H. C., Berg, M. P., \& de Vries, F. (2017). Litter for life: assessing the multifunctional legacy of plant traits. Journal of Ecology, 105(5), 1163-1168. DOI: 10.1111/1365-2745.12763

Duque, J., Arbeláez, S., Jaramillo, D., \& León, J. (2004). Estudio de hidrofobicidad de suelos en robledales (Quercus humboldtii) y plantaciones forestales (Pinus patula y Cupressus lusitanica) en la cuenca de la quebrada Piedras Blancas. Revista Facultad Nacional de Agronomía, 57, 2423.

FAO (2015). Global Forest Resources Assessment 2015. How are the world's forests changing? $\left(2^{\text {nd }} \mathrm{Ed}.\right)$. Rome: Food and Agriculture Organization of the United Nations.

Fernández, C., Lelong, B., Vila, B., Mévy, J. P., Robles, C., Greff, S., . . Bousquet-Mélou, A. (2006). Potential allelopathic effect of Pinus halepensis in the secondary succession: an experimental approach. Chemoecology, 16(2), 97-105. DOI: 10.1007/ s00049-006-0334-z

Gordon, C. A., Herrera, R., \& Hutchinson, T. C. (1994). Studies of fog events at two cloud forests near Caracas, Venezuela-I. Frequency and duration of fog. Atmospheric Environment, 28(2), 317-322.

Hokche, O, Berry, P. E., \& Huber, O. (2008) Nuevo Catálogo de la Flora Vascular de Venezuela. Caracas, Venezuela: Fundación Instituto Botánico de Venezuela "Dr. Tobías Lasser".

Houghton, R. (2005). Aboveground forest biomass and the global carbon balance. Global Change Biology, 11(6), 945-958.

Howorth, R. T., \& Pendry, C. A. (2006). Post-cultivation secondary succession in a Venezuelan lower montane rain forest. Biodiversity and Conservation, 15(2), 693-715. DOI: 10.1007/s10531-004-1061-9

Huber, O., \& Alarcón, C. (1988). Mapa de Vegetación de Venezuela. Escala 1:2.000.000. Caracas, Venezuela: Ministerio del Ambiente y Recursos Naturales Renovables, Dirección de Vegetación and The Nature Conservancy.

Jackson, M. (1982). Análisis químico de suelos. Barcelona, España: Omega.

Jackson, R. B., Jobbagy, E. G., Avissar, R., Roy, S. B., Barrett, D. J., Cook, C. W., . . Murray, B. C. (2005). Trading water for carbon with biological sequestration. Science, 310(5756), 1944-1947.

Koerselman, W., \& Meuleman, A. F. M. (1996). The vegetation N:P ratio: a new tool to detect the nature of nutrient limitation. Journal of Applied Ecology, 33, 1441-1450.

Lebrón, I., Robinson, D. A., Oatham, M., \& Wuddivira, M. N. (2012). Soil water repellency and $\mathrm{pH}$ soil change under tropical pine plantations compared with native tropical forest. Journal of Hydrology, 414, 194-200.

León, J. D., González-Hernández, M. I., \& GallardoLancho, J. F. (2010). Distribución del agua lluvia en tres bosques altoandinos de la Cordillera Central de Antioquia, Colombia. Revista Facultad Nacional de Agronomia, Medellín, 63(1), 5319-5336.

León, J. D., González, M. I., \& Gallardo, J. F. (2011). Biogeochemical cycles in natural forest and conifer plantations in the high mountains of Colombia. Revista de Biologia Tropical, 59(4), 1883-1894.

Li, Y., Xu, M., Zou, X., Shi, P., \& Zhang, Y. (2005). Comparing soil organic carbon dynamics in plantation and secondary forest in wet tropics in Puerto Rico. Global Change Biology, 11(2), 239-248. DOI: 10.1111/j.1365-2486.2005.00896.x

Loaiza-Usuga, J. C., León-Peláez, J. D., González-Hernández, M. I., Gallardo-Lancho, J. F., Osorio-Vega, W., \& Correa-Londoño, G. (2013). Alterations in litter decomposition patterns in tropical montane forests of Colombia: a comparison of oak forests and coniferous plantations. Canadian Journal of Forest Research, 43(6), 528-533. DOI: 10.1139/ cjfr-2012-0438

Lugo, A. E. (1992). Comparison of tropical tree plantations with secondary forests of similar age. Ecological Monographs, 62(1), 1-41.

Lugo, A. E. (2009). The emerging era of novel tropical forests. Biotropica, 41(5), 589-591. DOI: 10.1111/j.1744-7429.2009.00550.x

McDonald, T., Gann, G., Jonson, J., \& Dixon, K. (2016). International standards for the practice of ecological restoration - including principles and key concepts. Washington, D.C.: Society for Ecological Restoration.

Mehlich, A. (1984). Mehlich 3 soil test extractant: A modification of Mehlich 2 extractant. Communications in Soil Science and Plant Analysis, 15, 1409-1416.

Meier, W. (2011). Los bosques nublados de la Cordillera de la Costa en Venezuela. In G. Aymard (Ed.), Los Bosques de Venezuela (pp. 106-121). Guanare, Venezuela: UNELLEZ.

Millennium Ecosystem Assessment. (2005). Ecosystems and human well-being: A framework for Assessment. Washington, D.C.: Island Press.

Murphy, J., \& Riley, J. P. (1962). A modified single solution method for the determination of phosphate in natural waters. Analytica Chimica Acta, 27, 31-36.

Navarro-Cano, J.A., Barberá, G. G., \& Castillo, V. M. (2010). Pine litter from afforestations hinders the establishment of endemic plants in semiarid scrubby habitats 
of Natura 2000 Network. Restoration Ecology, 18(2), 165-169. DOI: 10.1111/j.1526-100X.2009.00606.x

Perfecto, I., \& Vandermeer, J. (2008). Biodiversity conservation in tropical agroecosystems: a new conservation paradigm. Annals of the New York Acaddemy of Sciences, 1134, 173-200. DOI: 10.1196/annals.1439.011

Portillo-Quintero, C., Lacabana, P., \& Carrasquel, F. (2011). Conversión de los bosques en la Cordillera de la Costa Central de Venezuela. In J. P. Rodríguez \& D. Giraldo (Ed.), Libro Rojo de los Ecosistemas Terrestres de Venezuela (pp. 239-243). Caracas, Venezuela: PROVITA, Shell Venezuela, Lenovo Venezuela.

Ramirez, J. A., León-Pelaez, J. D., Craven, D., Herrera D. A., Zapata, C. M., González-Hernandez, M. I., . . Osorio, W. (2014). Effects on nutrient cycling of conifer restoration in a degraded tropical montane forest. Plant And Soil, 378(1-2), 215-226. DOI: 10.1007/s11104-014-2024-x
Ruiz, O. A., Acosta Jaramillo, J. J., \& León Pelaez, J. D. (2005). Escorrentía superficial en bosques montanos naturales y plantados de Piedras Blancas, Antioquia (Colombia). Revista Facultad Nacional de Agronomía-Medellín, 58(1), 2635-2649.

Sobrado, M. A. (2003). Hydraulic characteristics and leaf water use efficiency in trees from tropical montane habitats. Trees - Structure and Function, 17(5), 400406. DOI: $10.1007 / \mathrm{s} 00468-003-0251-5$

Sparks, D., Page, A., Helmke, P., \& Loeppert, R. (1996). Methods of Soil Analysis. Part 3. Chemical Methods. Madison, Wisconsin, USA: Soil Science Society of America.

SYSTAT. (2002). SYSTAT for Windows v.10.0. IBM SPSS Software. Chicago, IL, USA.

Wright, I. J., Reich, P. B., Westoby, M., Ackerly, D. D., Baruch, Z., Bongers, F., . . . Villar, R. (2004). The worldwide leaf economics spectrum. Nature, 428(6985), 821-827. 